Удк 616.31-84

DOI

O.B. САВЧУK

\title{
РОЗШИРЕННЯ ПРОФІЛАКТИЧНОЇ СПРЯМОВАНОСТІ СТОМАТОЛОГІЧНОї ДОПОМОГИ
}

\author{
Національна медична академія післядипломної освіти імені П.Л. Шупика, м. Київ, Україна
}

Мета: обґрунтувати обсяги профілактичної допомоги в міській стоматологічній поліклініці і необхідну чисельність гігієністів стоматологічних.

Матеріали і методи. Експертна оцінка обсягів допомоги, які можуть бути передані для виконання гігієністам стоматологічним, виконана 12 експертами за методом Делфі. Визначення бюджету робочого часу гігієністів стоматологічних та обґрунтування їх необхідної штатної чисельності здійснено з використанням економічного методу і методу експертних оцінок.

Результати. Сформовано перелік видів робіт, які можуть виконуватися гігієністом стоматологічним. Визначено річний бюджет робочого часу однієї посади гігієніста стоматологічного та необхідну кількість ставок гігієністів стоматологічних для здійснення профрілактичної роботи в поліклініці.

Висновки Введення посад гігієністів стоматологічних дозволить розширити профілактичну спрямованість стоматологічної допомоги та сприятиме збереженню стоматологічного здоров'я населення.

КЛЮчОВІ СЛОВА: обсяг профілактичної роботи, гігієніст стоматологічний.

Важливим розділом діяльності лікувальнопрофрілактичних закладів охорони здоров'я, особливо первинної ланки, є профілактична робота. У період проведення економічних ресорм у країні в цілому і в охороні здоров'я зокрема, увага до профрілактичної роботи знизилася на всіх етапах надання медичної допомоги населенню [1;2;5].

На даний час стоматологічна допомога належить до найбільш масових видів медичної допомоги. Питома вага стоматологічних захворювань у структурі загальної захворюваності населення за зверненнями досягає 20-25\%, а її рівень становить 345-550 випадків на 1000 жителів. Аналіз літератури свідчить про високу поширеність та інтенсивність основних стоматологічних захворювань - карієсу зубів і захворювань пародонту в основних вікових групах населення [3;7].

Досвід багатьох країн показав, що збільшення кількості персоналу, фрінансування та матеріального забезпечення стоматологічної служби недостатньо для поліпшення стоматологічного здоров'я населення. Передусім необхідно змінити пріоритети і приділити належну увагу профрілактиці стоматологічних захворювань, у тому числі навчанню персоналу для реалізації цього виду профресійної діяльності [4;6].

Мета роботи: обґрунтувати обсяги профілактичної допомоги в міській стоматологічній поліклініці та необхідну чисельність гігієністів стоматологічних.

Матеріали і методи. Експертна оцінка обсягів допомоги, які можуть бути передані для виконання гігієністам стоматологічним, виконана 12 експертами (лікарями-стоматологами 3 вищою кваліфікаційною категорією) за методом Делфі. Визначення бюджету робочого часу гігієністів стоматологічних та обґрунтування їх необхідної штатної чисельності здійснено з використанням економічного методу і методу експертних оцінок. Статистична обробка результатів дослідження передбачала варіаційний аналіз і ви-

(с) О.В. Савчук, 2015 значення коефріцієнта конкордації та виконана із застосуванням статистичного пакету Statistica 8.0.

Результати дослідження та їх обговорення. Необхідною умовою ефективної реалізації програм профрілактики стоматологічних захворювань $€$ визначення поширеності та інтенсивності карієсу тимчасових і постійних зубів, а також вивчення їх динаміки у ключових вікових групах населення.

При аналізі статистичних матеріалів встановлено, що первинна захворюваність населення м. Києва хворобами порожнини рота і зубів протягом останніх років продовжує зростати і становила в середньому 115,3 випадку на 1000 дітей у віці 0-14 років, а серед підлітків у віці 15-17 років 218,1 випадку на 1000 відповідного населення.

Нами проведена експертна оцінка видів профрілактичної стоматологічної діяльності, яку можна передати гігієністам стоматологічним. Експертна оцінка здійснювалася за складеним класифікатором робіт. Експертиза проводилася у три етапи. На першому етапі кожен з експертів виставляв незалежні оцінки (за десятибальною шкалою) по кожному із пропонованих видів робіт. На другому і третьому етапах експерти зіставляли свою думку з колективною оцінкою всієї експертної групи, при цьому вони могли змінити або скорегувати свою позицію.

За результатами третього етапу експертної оцінки розрахований середній бал для кожного виду робіт (M) і його помилка (m). У таблиці показані види робіт, які за результатами експертної оцінки отримали найвищі бали (9 і більше).

Узгодженість думки експертів визначалася за коефріцієнтом конкордації (W). Його високе значення $(\mathrm{W}=0,78)$ свідчить про узгодженість оцінок експертів.

Наступним етапом роботи з визначення потреби населення в лікарях-гігієністах стоматологічних були розрахунки витрат часу на проведення кожного виду робіт. 3 цією метою також було використано метод експертних оцінок з триразовим опитуванням експертів. 
Таблиця. Перелік видів робіт, які можуть виконуватися гігієністом стоматологічним

\begin{tabular}{|c|c|c|}
\hline $\begin{array}{l}\text { № } \\
3 / \text { ח }\end{array}$ & Вид роботи & 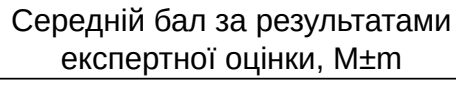 \\
\hline 1 & $\begin{array}{l}\text { Підготовка матеріалів щодо пропаганди здорового способу життя, раціо- } \\
\text { нального харчування, профрілактики стоматологічних захворювань }\end{array}$ & $9,34 \pm 0,15$ \\
\hline 2 & Оорормлення куточків гігієни в поліклініці & $9,66 \pm 0,12$ \\
\hline 3 & Офрормлення куточків гігієни в дитячих дошкільних установах і школах & $9,39 \pm 0,15$ \\
\hline 4 & Офрормлення куточків гігієни в освітніх установах, на підприємствах & $9,10 \pm 0,17$ \\
\hline 5 & $\begin{array}{l}\text { Проведення бесід з профрілактики стоматологічних захворювань в органі- } \\
\text { зованих колективах }\end{array}$ & $9,66 \pm 0,12$ \\
\hline 6 & $\begin{array}{l}\text { Видалення зубного нальоту, бляшки за допомогою фрлосів, зубних } \\
\text { йоржиків, з подальшим поліруванням зубів }\end{array}$ & $9,21 \pm 0,14$ \\
\hline 7 & Покриття зубів фрторлаком, фрторгелем & $9,32 \pm 0,15$ \\
\hline 8 & Навчання методиці чищення зубів & $9,80 \pm 0,10$ \\
\hline 9 & $\begin{array}{l}\text { Просрілактика карієсу за допомогою місцевих срторвмісних препаратів } \\
\text { (розчини) }\end{array}$ & $9,52 \pm 0,12$ \\
\hline 10 & Профрілактика фрісурного карієсу (мінеральна герметизація фрісур) & $9,80 \pm 0,10$ \\
\hline 11 & Ремінералізуюча терапія (глибоке срторування) & $9,54 \pm 0,12$ \\
\hline 12 & Проведення герметизації фрісур (неінвазивна методика) & $9,37 \pm 0,15$ \\
\hline 13. & Видалення над- і під'ясенних зубних відкладень & $9,77 \pm 0,10$ \\
\hline 14 & $\begin{array}{l}\text { Індивідуальний підбір щітки і пасти пацієнтові з урахуванням стану } \\
\text { здоров'я та віку }\end{array}$ & $9,41 \pm 0,15$ \\
\hline 15 & $\begin{array}{l}\text { Рекомендації по догляду за порожниною рота за наявності протезів, } \\
\text { брекет-систем }\end{array}$ & $9,59 \pm 0,12$ \\
\hline 16 & $\begin{array}{l}\text { Групова профілактика карієсу зубів і захворювань пародонту в організова- } \\
\text { них дитячих колективах }\end{array}$ & $9,41 \pm 0,15$ \\
\hline 17 & Навчання чищенню зубів дорослих і дітей в організованих колективах & $9,11 \pm 0,17$ \\
\hline 18 & Організований профрілактичний огляд дорослого населення & $9,87 \pm 0,09$ \\
\hline 19 & Профрілактичний огляд дітей в організованих дитячих колективах & $9,61 \pm 0,12$ \\
\hline
\end{tabular}

3 метою контролю отриманих нами даних було проведено зіставлення витрат часу на виконання різних видів профрілактичних робіт 3 витратами часу, рекомендованими на виконання аналогічних робіт класиорікатором стоматологічних послуг.

Витрати часу на виконання видів діяльності гігієніста стоматологічного, визначені в ході цього дослідження, також не мають різких відмінностей від витрат часу на проведення профрілактичних заходів, рекомендованих для стоматологічних установ на державному рівні.

Обсяг діяльності фрахівця визначається переліком видів виконуваних ним робіт, витратами часу на виробництво кожного їх виду, а також частотою повторення трудових операцій у певний період часу.

Зіставлення експертних даних про необхідний обсяг виконання профрілактичних заходів 3 фрактично виконаним рівнем профрілактичної роботи в стоматологічній поліклініці м. Києва у 2014 р. дозволяє зробити висновок, що експерти вважають за необхідне здійснити реструктуризацію проведених заходів, скорочуючи рівень виконання одних процедур за рахунок розширення інших, які більше відповідають структурі патології населення.

Як показали розрахунки, на виконання усіх видів робіт, наявних у сорормованому класифікаторі гігієніста стоматологічного, які повинні бути реалізовані з метою розширення профрілактичної спрямованості стоматологічної допомоги, і забезпечення потреби населення в даному виді послуг протягом календарного року має бути витрачено 504351,2 хвилини робочого часу. Річний бюджет робочого часу однієї посади гігієніста стоматологічного складе 82980 хвилин. Отже, для виконання планового обсягу роботи необхідно 6,0 посад гігієніста стоматологічного.

Основним напрямком діяльності нововведених посад гігієністів стоматологічних буде проведення профрілактичної роботи серед населення, що веде до зниження поширеності та інтенсивності стоматологічних захворювань.

Говорячи про профрілактику, фрахівці зазвичай акцентують увагу на масових захворюваннях, одним $з$ яких є карієс зубів, на частку якого, за даними стоматологічної поліклініки м. Києва, припадає 52\% усіх звернень до лікаря-фрахівця.

Оскільки поліклініка працює $з$ відносним перевантаженням, при введенні в штатну структуруполіклініки гігієністів стоматологічних частину функцій лікарів-стоматологів буде передано рекомендованим фрахівцям, що призведе до вивільнення лікарів-стоматологів для виконання інших видів стоматологічної допомоги.

\section{Висновки}

Медико-економічне обґрунтування обсягів профрілактичної роботи в стоматологічній поліклініці 
дозволило розрахувати річний бюджет робочого часу на виконання всіх видів робіт, які повинні бути реалізовані з метою розширення профрілактичної спрямованості стоматологічної допомоги та забезпечення потреби населення в даному виді послуг, а також розрахувати кількість необхідних штатних одиниць посад гігієніста стоматологічного та запропонувати відповідні зміни до штатного розпису стоматологічної поліклініки.
Введення посад гігієністів стоматологічних дозволить розширити профрілактичну спрямованість стоматологічної допомоги та сприятиме збереженню стоматологічного здоров'я населення.

Перспективи подальших досліджень пов'язані з розробкою заходів, спрямованих на покращення якості надання стоматологічної допомоги населенню в Україні.

\section{Список літератури}

1. Джегус И. Т. Психодент / И. Т. Джегус. - Харьков : СиМ, 2008. -244.

2. Леманн К. Основы терапевтической и ортопедической стоматологи / К. Леманн, Э. Хельвег. - Львов, 1999. - 343 с.

3. Максимовский Ю. М. Основы профилактики стоматологических заболеваний : учебное пособие / Ю. М. Максимовский, О. В. Сагина. - Москва : Владос-Пресс, 2005. - 208 с.

4. Муравянникова Ж. Г. Диагностика и профрилактика стоматологических заболеваний / Ж. Г. Муравянникова, О. В. Панаиотова. - Ростов-на-Дону : Феникс, 2013. - 512 с.

5. Попруженко Т. В. Профилактика основных стоматологических заболеваний / Т. В. Попруженко, Т. Н. Терехова. Москва : МЕДпресс-инсрорм, 2009. - 464 с.

6. Руле Ж. Ф. Профрессиональная профилактика в практике стоматолога / Ж. Ф. Руле, Стесран Циммер. - Москва : МЕДпресс-инорорм, 2010. - 610 с.

7. Терапевтическая стоматология : учебник для студентов медвузов, обучающихся по специальности «стоматология» / под ред. В. В. Боровського. - Москва : Медицина, МИА, 2011. - 799 с.

\section{РАСШИРЕНИЕ ПРОФИЛАКТИЧЕСКОЙ НАПРАВЛЕННОСТИ СТОМАТОЛОГИЧЕСКОЙ ПОМОЩИ}

O.В. Савчук

Национальная медицинская академия последипломного образования имени П.Л. Шупика, г. Киев, Украина

Цель: обосновать объемы профилактической помощи в городской стоматологической поликлинике и необходимое количество гигиенистов стоматологических.

Материалы и методы. Экспертная оценка объемов помощи, которые могут быть переданы гигиенистам стоматологическим, проведена 12 экспертами по методу Делфи. Определение бюджета рабочего времени гигиенистов стоматологических и обоснование их необходимого штатного количества осуществлялось с использованием экономического метода и метода экспертных оценок.

Результаты. Сфрормирован перечень видов работ, которые могут проводиться гигиенистом стоматологическим. Определены годовой бюджет рабочего времени одной должности гигиениста стоматологического и необходимое количество ставок гигиенистов стоматологических для ведения просрилактической работы в поликлинике.

Выводы. Введение должностей гигиенистов стоматологических позволит расширить профрилактическую направленность стоматологической помощи и будет способствовать сохранению стоматологического здоровья населения.

КЛЮЧЕВЫЕ СЛОВА: объем профилактической работы гигиенист стоматологический.

\section{EXPANSION OF PREVENTATIVE DENTAL CARE}

O.V. Savchuk

Shupyk National Medical Academy of Postgraduate Education, Kyiv, Ukraine

Purpose: to prove the amounts of preventive care in the city dental clinic and necessary number of dental hygienists.

Materials and methods. Expert estimation of care volumes, which can be transferred for performance to dental hygienist, made by 12 experts on Delphi method. The budget working hours of dental hygienists and substantiation of their necessary regular number is carried out using economic methods and methods of expert estimations.

Results. The list of types of work, which can be carried out by dental hygienist is generated. The annual budget working hours of one position of dental hygienist and necessary quantity of dental hygienists rates to carry out of preventive work in the clinic have been determined.

Conclusions. Introduction of hygienists dental posts will allow to expand the focus of preventive dental care and will promote preservation of dental health of the population.

KEY WORDS: volumes prevention, dental hygienists.

Рукопис надійшов до редакції 16.11.2015 p.

Відомості про автора

Савчук Олег Володимирович - к.мед.н. доц. кафедри стоматології НМАПО ім. П.Л. Шупика;

тел. служб.: +38(044) 482-08-41 